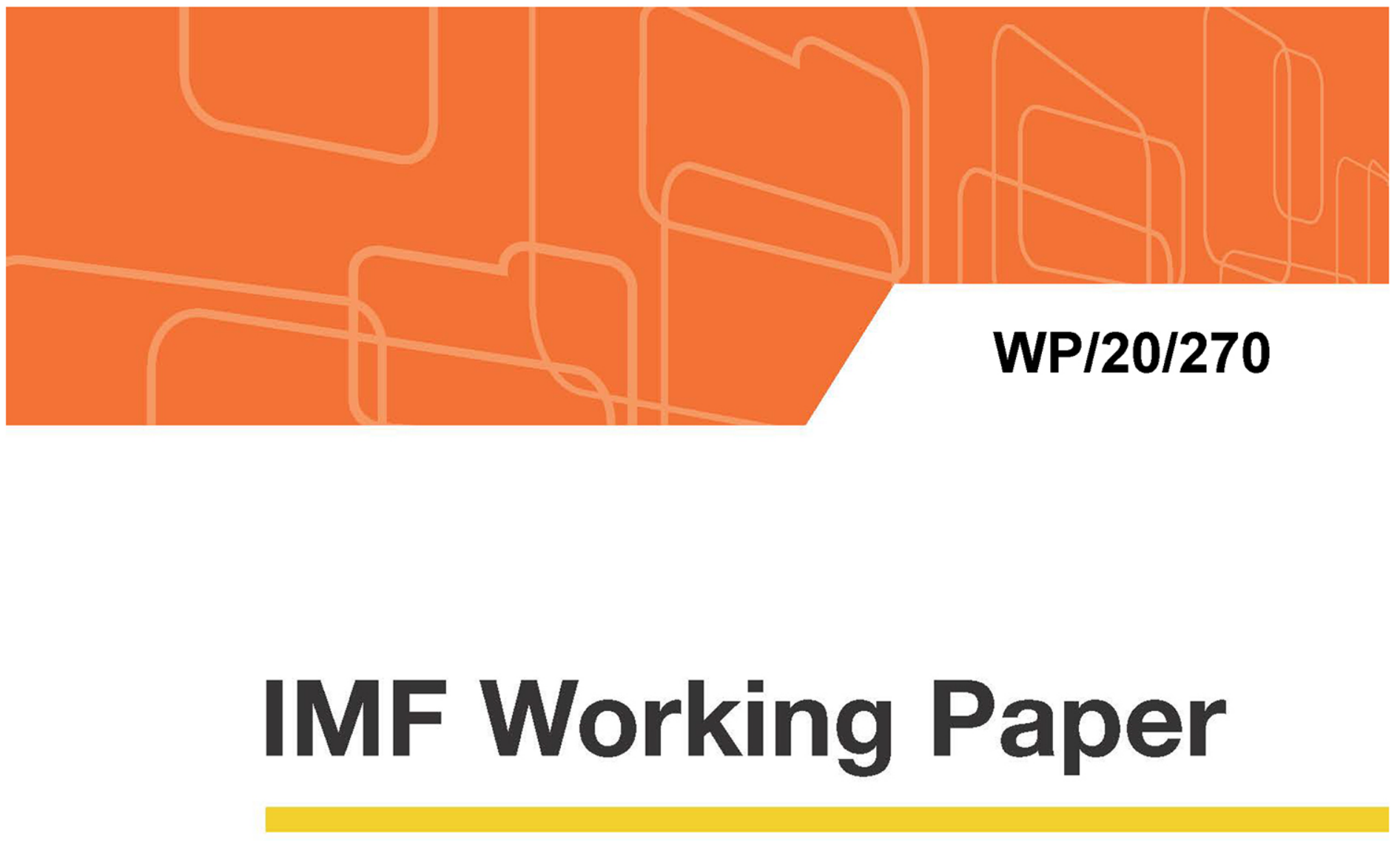

\title{
Confidence as a Driver of Private Investment in Selected Countries of Central America
}

by Carlos Janada and Iulia Ruxandra Teodoru

IMF Working Papers describe research in progress by the author(s) and are published to elicit comments and to encourage debate. The views expressed in IMF Working Papers are those of the author(s) and do not necessarily represent the views of the IMF, its Executive Board, or IMF management. 


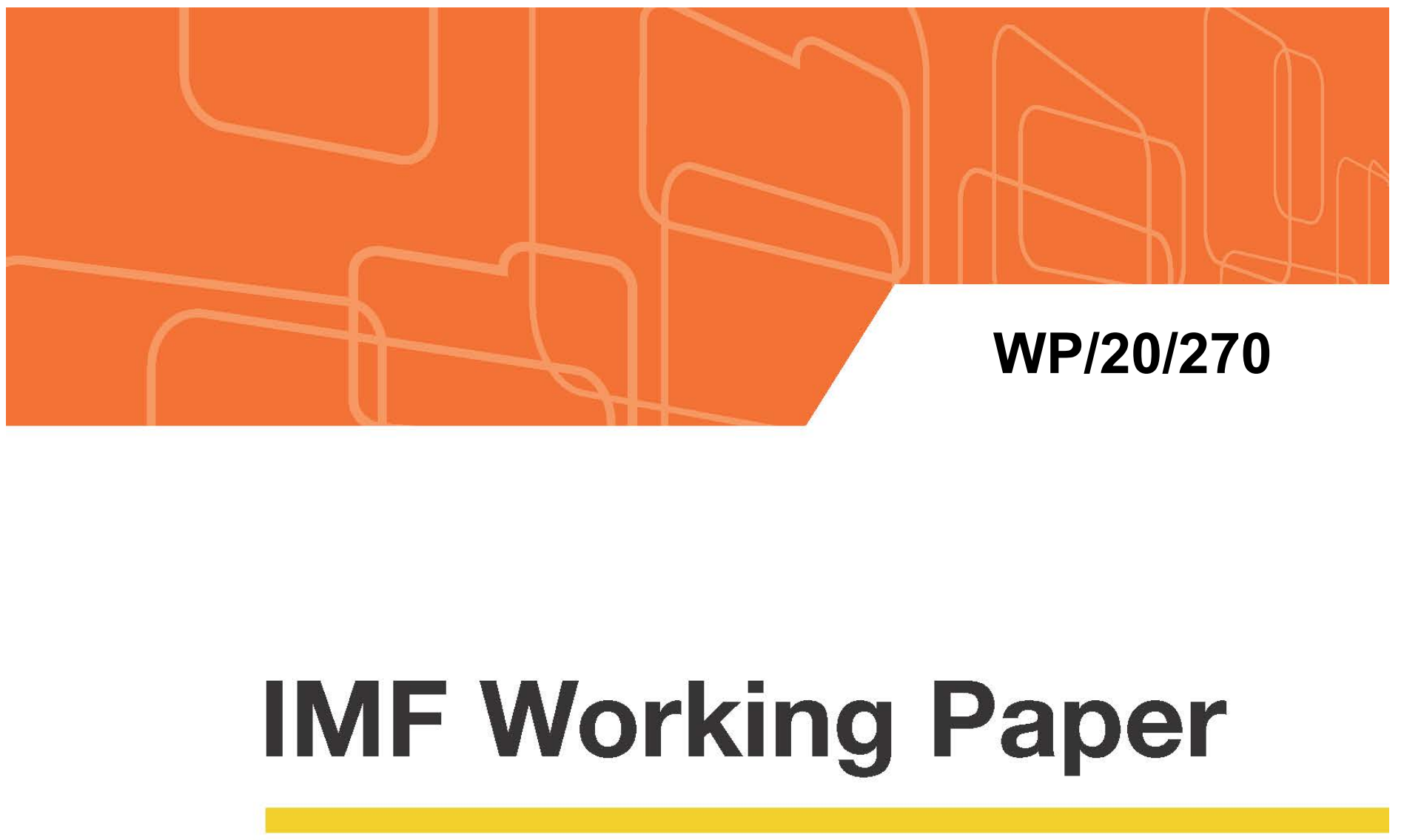

\section{Confidence as a Driver of Private Investment in Selected Countries of Central America}

by Carlos Janada and lulia Ruxandra Teodoru

IMF Working Papers describe research in progress by the author(s) and are published to elicit comments and to encourage debate. The views expressed in IMF Working Papers are those of the author(s) and do not necessarily represent the views of the IMF, its Executive Board, or IMF management. 


\title{
IMF Working Paper
}

\author{
Western Hemisphere Department
}

Confidence as a Driver of Private Investment in Selected Countries of Central America

\section{Prepared by Carlos Janada and Iulia Ruxandra Teodoru ${ }^{1}$}

\author{
Authorized for distribution by Inci Otker
}

December 2020

IMF Working Papers describe research in progress by the author(s) and are published to elicit comments and to encourage debate. The views expressed in IMF Working Papers are those of the author(s) and do not necessarily represent the views of the IMF, its Executive Board, or IMF management.

\begin{abstract}
This paper argues that structural weaknesses may make private investment particularly sensitive to business confidence relative to other traditional investment drivers and global shocks. It gauges the importance of confidence over recent years in selected countries in Central America, including Costa Rica, the Dominican Republic, El Salvador, and Guatemala. Using a vector error correction model to carry out the empirical work, a system representing global activity and the domestic economy, including a set of investment drivers (interest rates, unit labor costs, and confidence) is analyzed. The findings suggest that confidence has been, on average, the most important driver of investment in these countries, exceeded only by global factors. Since confidence, arguably, can be influenced by policymakers' decisions, structural reforms to improve the business climate and reduce uncertainty play an important role in promoting investment and economic growth.
\end{abstract}

JEL Classification Numbers: E22

Keywords: determinants of investment, confidence, uncertainty, VAR, VECM Author's E-Mail Address: cjanada@imf.org; iteodoru@imf.org

\footnotetext{
${ }^{1}$ We are grateful to Inci Otker, Ravi Balakrishnan, Fernando Delgado, Torsten Wezel, Olga Bespalova, Alina Carare, Aliona Cebotari, Esther Perez Ruiz, and Marina Vladimirovna Rousset for insightful comments on preliminary versions of this paper, and to Banguat's Research Department for the thorough comments received during a Seminar presentation, as well as, to those from the Banco Central de Costa Rica. We thank Cristhian Vera Avellan for excellent research assistance and Xingwei Hu for his invaluable programming assistance with Eviews ${ }^{\circledR}$. We are also thankful to the Union of Chambers and Associations of the Private Sector (Costa Rica), Association for Industries (the Dominican Republic), Fusades (El Salvador), and Bank of Guatemala for providing key statistical data.
} 
I. Introduction $\underline{3}$

II. Factors Affecting Investment __ $\underline{5}$

III. Empirical Analysis___ 2

IV. Concluding Remarks _ـ 20

\section{Figures}

1. Investment and Growth

2. Investment Climate Indicators

3. Business Confidence Indices

4. Response to Cholesky One S.D. Innovations

$\underline{18}$

\section{Tables}

1. Investment Ratio and Growth Convergence to U.S. (1990-2017) __ 4

2. Business Confidence Indexes in Central America

3. Augmented Dickey-Fuller Unit Root Test Statistic with Constant \& Trend

4. Contributions to Investment Residuals-Baseline ___ 16

5. Main Test Results

6. Contributions to Investment Residuals-Alternative 1

7. Contributions to Investment Residuals-Alternative 2

\section{Annexes}

I. Business Confidence Indices in Costa Rica, Dominican Republic, El Salvador and Guatemala

II. Some Methodological Notes

III. Historical Decomposition of the Investment Residual 


\section{INTRODUCTION}

Four Central American economies - Costa Rica, the Dominican Republic, El Salvador, and Guatemala - have experienced different outcomes of convergence to U.S. growth, which may have been driven, in part, by insufficient investment. Low investment ratios in El Salvador and Guatemala, for example, seem to have impaired convergence (Figure 1 and Table 1). In 1990-2017, the investment ratio in percent of GDP stood at 16.7 percent for El Salvador and Guatemala - less than two-thirds of the EMDEs' investment ratio of 26.2 percent (Table 1).

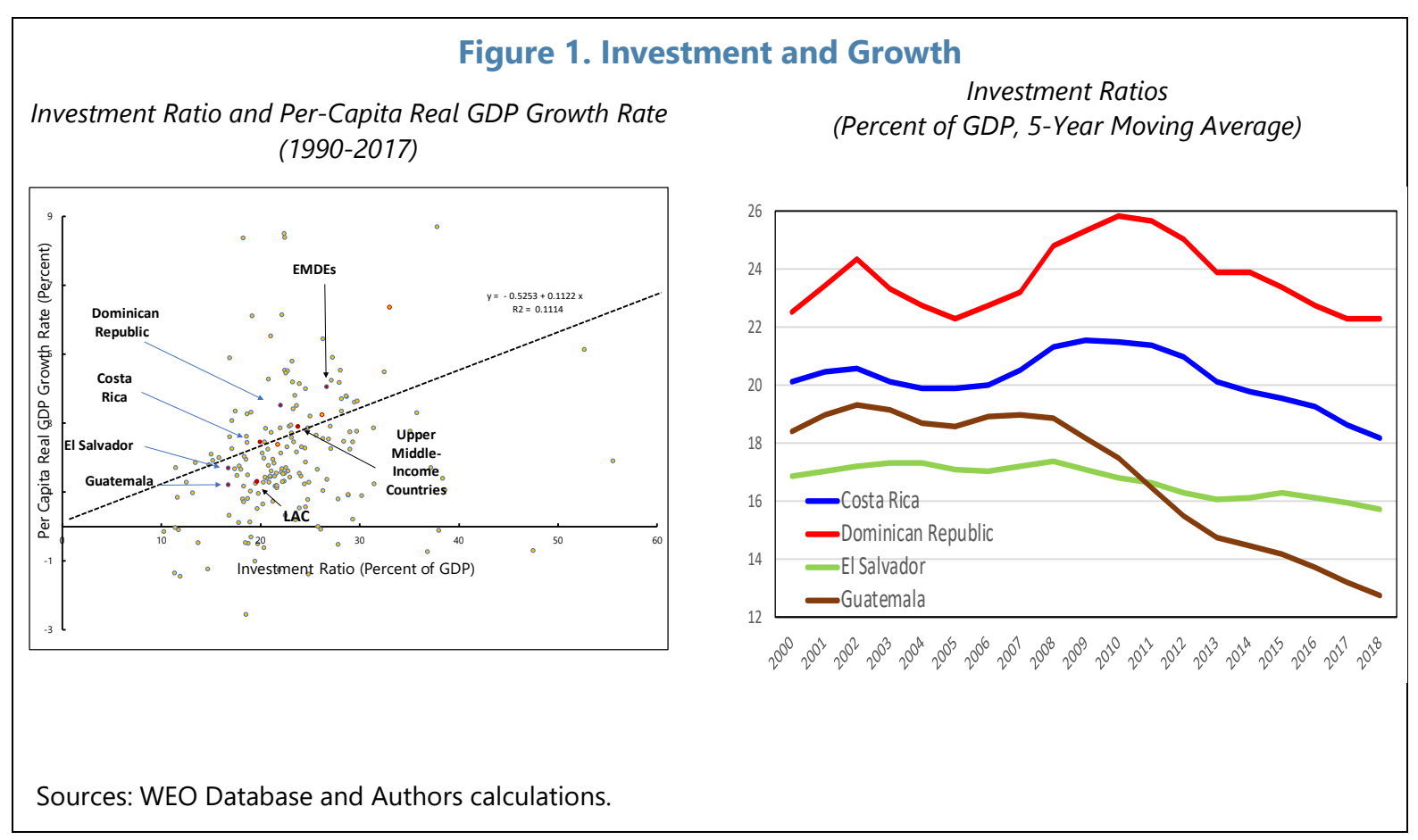

Costa Rica and the Dominican Republic fared better, due, in part, to their higher, albeit declining, investment ratios. They were able to transform from agriculture-based to manufacturing-dominated economies, and more recently expand into service-oriented industries, all of which have contributed to higher per capita incomes, diversification of their economies, and social development. ${ }^{2}$ In the period 1990-2017, the average investment ratio stood at 20 percent for Costa Rica, and 22 percent for the Dominican Republic (Table 1). Convergence gaps in Costa Rica and the Dominican Republic have been reduced significantly.

\footnotetext{
${ }^{2}$ See Figliuoli and García-Saltos (2019), Chapter I: Building a Foundation for Sustained Growth.
} 
Table 1. Investment Ratios and Growth Convergence to U.S. (1990-2017)

\begin{tabular}{|c|c|c|c|c|c|c|c|c|}
\hline & \multicolumn{2}{|c|}{ 1990-2017 } & \multicolumn{2}{|c|}{$\begin{array}{l}\text { Per-Capita PPP GDP, } \\
\text { PPP USD }\end{array}$} & \multirow[b]{2}{*}{ (2) / (1) } & \multicolumn{3}{|c|}{ Convergence to U.S. Growth } \\
\hline & $\begin{array}{l}\text { Investment } \\
\text { Ratio, } \\
\text { percent of } \\
\text { GDP }\end{array}$ & $\begin{array}{c}\text { Per-Capita } \\
\text { Real GDP } \\
\text { Growth Rate, } \\
\text { percent }\end{array}$ & $\begin{array}{l}\text { 1990-92 } \\
\text { (1) }\end{array}$ & $\begin{array}{l}\text { 2015-17 } \\
\text { (2) }\end{array}$ & & $\begin{array}{c}\text { (1) as a } \\
\text { percent of } \\
\text { Per-Capita } \\
\text { U.S. GDP, } \\
1990-92 \\
\text { (3) }\end{array}$ & $\begin{array}{c}\text { (2) as a } \\
\text { percent of } \\
\text { Per-Capita } \\
\text { U.S. GDP, } \\
2015-17 \\
\text { (4) } \\
\end{array}$ & $\begin{array}{c}\text { Percent } \\
\text { increase or } \\
\text { decrease } \\
\text { between (4) } \\
\text { and (3) }\end{array}$ \\
\hline Emerging Asia & 33.0 & 6.4 & 1,479 & 11,348 & 7.7 & 6.0 & 19.5 & 223.3 \\
\hline Emerging Market and Developing Economies & 26.2 & 3.3 & 2,820 & 11,317 & 4.0 & 11.5 & 19.5 & 69.1 \\
\hline Latin America and the Caribbean & 19.6 & 1.3 & 6,817 & 15,672 & 2.3 & 27.8 & 26.9 & -3.1 \\
\hline Upper-Middle Income Countries & 23.8 & 2.9 & 5,797 & 14,473 & 2.5 & 23.6 & 24.9 & 5.2 \\
\hline CAPDR & 21.7 & 2.4 & 3,909 & 12,650 & 3.2 & 15.9 & 21.7 & 36.4 \\
\hline Costa Rica & 20.0 & 2.5 & 5,416 & 16,255 & 3.0 & 22.1 & 27.9 & 26.5 \\
\hline the Dominican Republic & 22.0 & 3.5 & 3,792 & 16,071 & 4.2 & 15.5 & 27.6 & 78.6 \\
\hline El Salvador & 16.7 & 1.7 & 3,087 & 7,509 & 2.4 & 12.6 & 12.9 & 2.5 \\
\hline Guatemala & 16.7 & 1.2 & 3,604 & 7,970 & 2.2 & 14.7 & 13.7 & -6.8 \\
\hline Honduras & 24.9 & 1.3 & 2,114 & 4,790 & 2.3 & 8.6 & 8.2 & -4.5 \\
\hline Nicaragua & 23.6 & 2.2 & 2,164 & 5,563 & 2.6 & 8.8 & 9.6 & 8.3 \\
\hline Panama & 28.0 & 4.2 & 5,440 & 23,306 & 4.3 & 22.2 & 40.1 & 80.5 \\
\hline the Dominican Republic and Panama & 25.0 & 3.8 & 4,616 & 19,689 & 4.3 & 18.8 & 33.8 & 79.7 \\
\hline Northern Triangle Countries & 19.4 & 1.4 & 2,935 & 6,756 & 2.3 & 12.0 & 11.6 & -3.0 \\
\hline \multicolumn{9}{|c|}{ 1/ For comparators, figures report country group averages. For countries, yearly averages. } \\
\hline $\begin{array}{l}\text { Emerging Asia: China, Hong Kong, Indonesia, India, } \\
\text { UMI Countries: Albania, Algeria, Armenia, Azerbaija } \\
\text { Domincan Republic, Ecuador, Equatorial Guinea, Fij } \\
\text { Marshall Islands, Mauritius, Mexico, Montenegro, N } \\
\text { Suriname, Thailand, Tonga, Turkey, Turkmenistan, T } \\
\text { were omitted. } \\
\text { CAPDR: Costa Rica, Dominican Republic, El Salvado } \\
\text { NTC: El Salvador, Guatemala and Honduras. }\end{array}$ & $\begin{array}{l}\text { Duth Korea, Ma } \\
\text { Belarus, Belize, } \\
\text { Sabon, Grenada } \\
\text { iibia, Nauru, Pa } \\
\text { alu and Venezu } \\
\text { Honduras, Guat }\end{array}$ & $\begin{array}{l}\text { laysiua, Philippin } \\
\text { Bosnia and Herz } \\
\text { Guatemala, Gu } \\
\text { raguay, Peru, Ro } \\
\text { ela. American S } \\
\text { emala, Nicaragu }\end{array}$ & $\begin{array}{l}\text { ingapore an } \\
\text { ina, Botswa } \\
\text {, Iran, Iraq, J } \\
\text { ia, Russia, S } \\
\text { a, Cuba and } \\
\text { d Panama. }\end{array}$ & $\begin{array}{l}\text { ailand. } \\
\text { Brazil, Bulga } \\
\text { ica, Jordan, } \\
\text { a, Serbia, Sc } \\
\text { edona, FYR }\end{array}$ & $\begin{array}{l}\text { Cameroon, } \\
\text { akhstan, Lel } \\
\text { Afria, St. Lu } \\
\text { also UMI m }\end{array}$ & $\begin{array}{l}\text { na, Colombia, } \\
\text { Ion, Libya, Mal } \\
\text {, St. Vincent a } \\
\text { bers but due } t\end{array}$ & $\begin{array}{l}\text { osta Rica, Dom } \\
\text { ysia, Maldives, } \\
\text { d the Grenadin } \\
\text { data limitatio }\end{array}$ & $\begin{array}{l}\text { inica, } \\
\text { es, } \\
\text { ss }\end{array}$ \\
\hline
\end{tabular}

Investment ratios have been declining across all four countries, and in this context, it is useful to explore the drivers of investment. This paper analyzes empirically the potential drivers of private investment in a subset of the Central America, Panama, and the Dominican Republic (CAPDR) region. It excludes Honduras, Nicaragua, and Panama due to data limitations. Among the four CAPDR countries, El Salvador and Guatemala have low investment ratios and limited growth prospects, Costa Rica faces fiscal and financial vulnerabilities, which may weigh on investment and growth prospects, while the Dominican Republic enjoys higher investment ratios and better growth prospects.

Our findings suggest that confidence is the driver with the largest impact on investment residuals, exceeded only by global shocks. ${ }^{3}$ Confidence shocks accounted for well-over one sixth of the investment residuals across all countries, while global factors, represented slightly more than one fifth. The contribution of interest rate shocks came in third place, accounting for about one seventh of the investment residuals. GDP and unit labor costs

\footnotetext{
${ }^{3}$ In an inter-dependent dynamic system, a shock in one variable has an immediate impact on itself and, overtime, on some others as well, such that there is a direct and indirect impact. Historical Decomposition provides a comprehensive estimate of the overall impact of a shock overtime. This accounting technique is used in this paper to estimate the relative importance of the drivers of private investment. See Burbidge and Harrison (1985) for an explanation of this technique when analyzing the role of money during the Great Depression.
} 
shocks were the fourth and fifth contributors, with slightly less than one twentieth and one thirtieth of the total, respectively.

The rest of the paper is organized as follows: Section II reviews the literature and presents some stylized facts on factors affecting investment. Section III presents the model specifications, discusses the data, some measurement issues, stationarity of the time series. and analyzes the estimation results. Section IV concludes with some final remarks.

\section{FaCtors AfFecting InVESTMEnT}

Detrimental business climate conditions, weak rule of law, limited investor protection, or political instability may be among the structural weaknesses affecting investment in the sample countries with varying intensities. Comparative indicators (Worldwide Governance Indicators, World Bank Doing Business Index, and business surveys of the World Economic Forum) reveal that starting a business, dealing with construction permits, getting credit and electricity, and trading across borders have much room for improvement in the Dominican Republic, El Salvador, and Guatemala (Figure 2). High crime (El Salvador and Guatemala), corruption (Dominican Republic, El Salvador, and Guatemala), and political instability (Dominican Republic, El Salvador, and Guatemala) are some of the impediments to doing business. In terms of the overall business climate and competitiveness, the World Economic Forum's Global Competitiveness Report places Costa Rica above the 60th percentile rank, while the Dominican Republic, El Salvador, and Guatemala rank much lower, with significant lags with respect to innovation capability and information and communications technology adoption, institutions, market size, and skills. The corporate income tax rate is not particularly high, except in El Salvador (where the rate is 35 percent, as it includes an additional 5 percentage points security tax). However, business surveys identify tax rates as one of the most problematic factors for doing business in Costa Rica and the Dominican Republic.

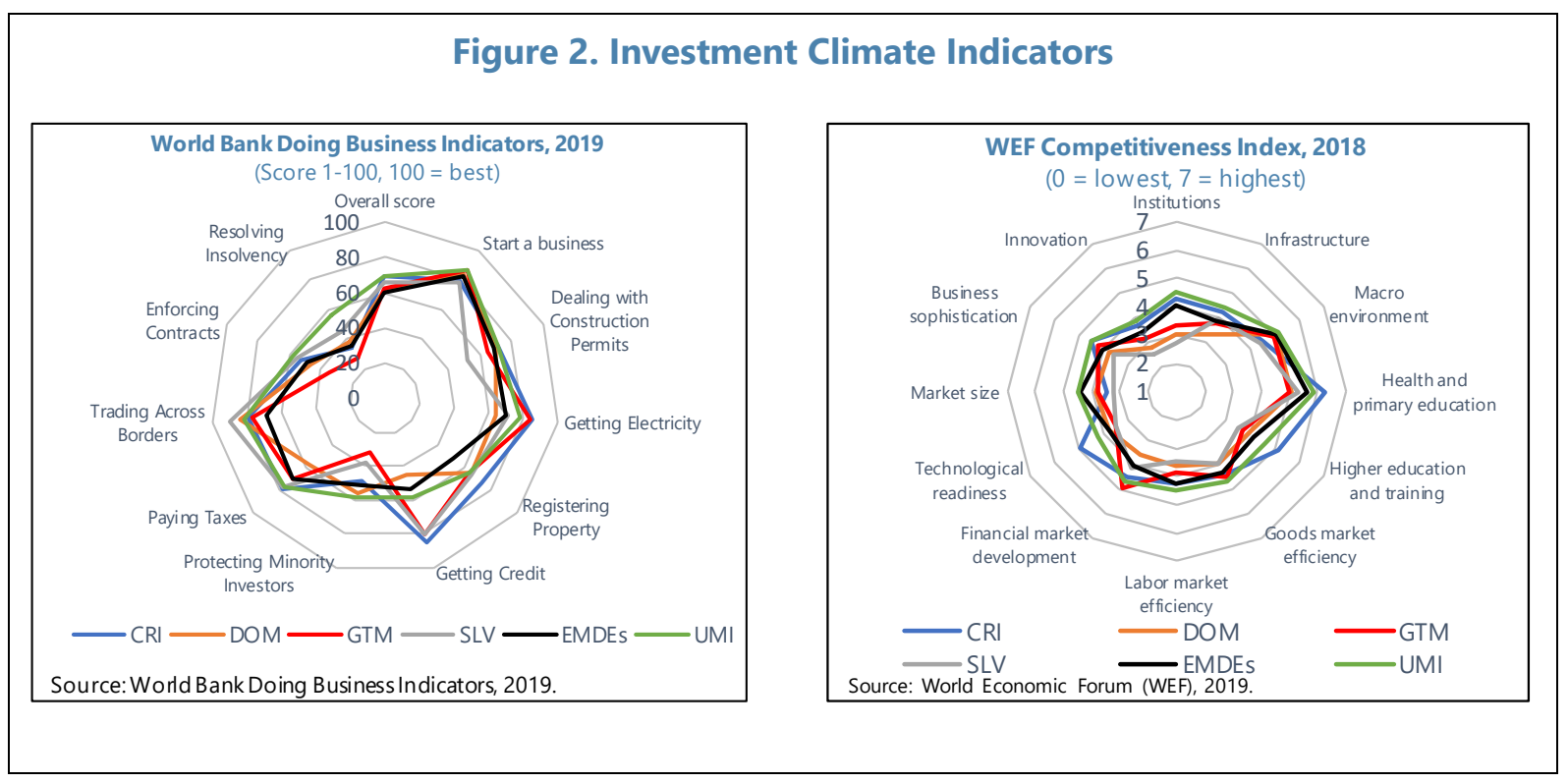




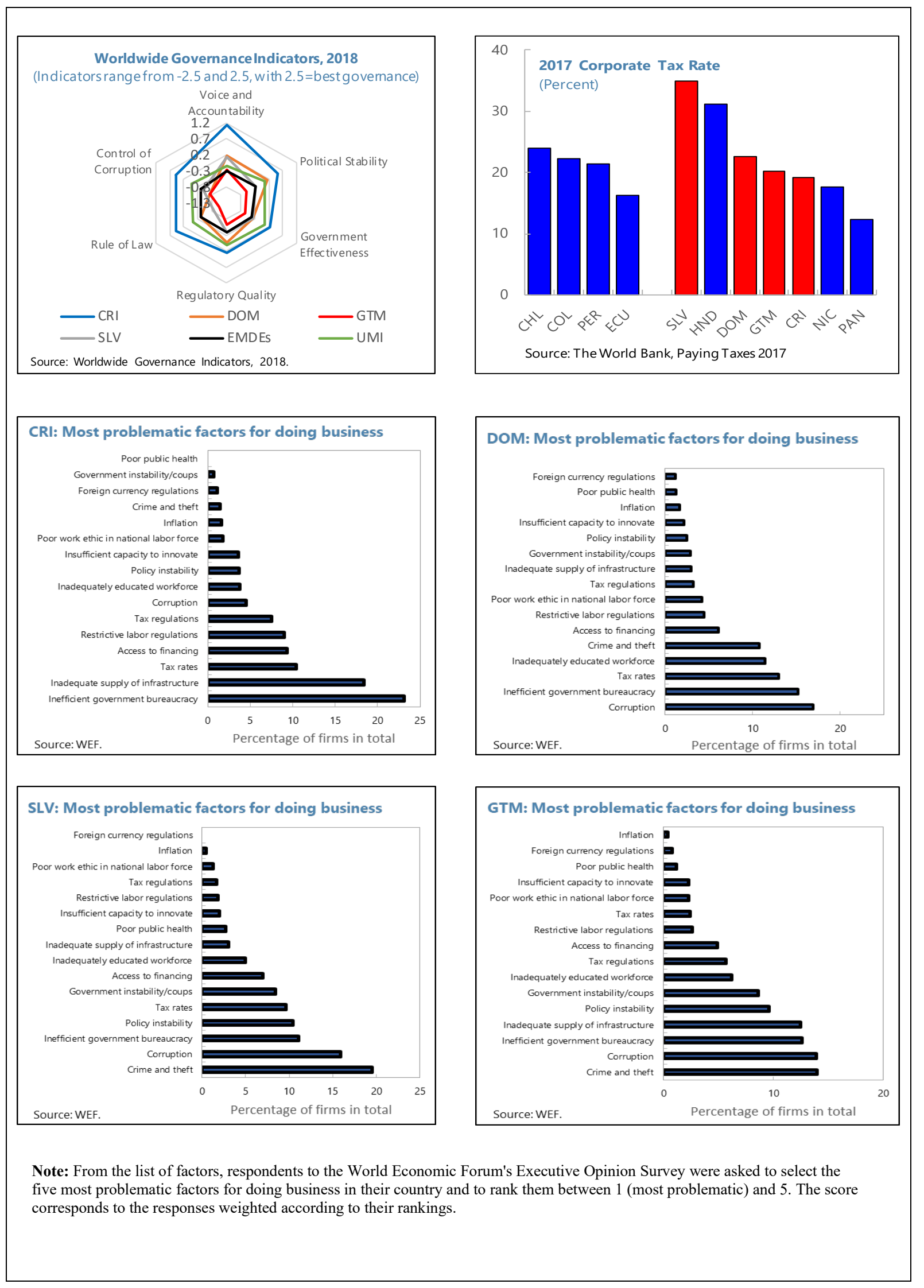


These structural weaknesses increase the costs of doing business, including the uncertainty surrounding business prospects. The question for research is how strong the link is between investment and business uncertainty/confidence. Shifts in the perception of current economic conditions and expectations for the future, drive current and future investment decisions.

Firms may become cautious about investment and hiring if they lack confidence in the economic conditions they operate in and are unable to forecast the future with certainty. If structural weaknesses in the rule of law and business climate, or political instability, are prevalent, poor confidence will persist or could even rise, and thus, investment spending is perpetually delayed or even reduced. ${ }^{4}$

Business confidence has deteriorated more recently in Costa Rica and Guatemala, and it has been lower than before the global financial crisis (GFC) in El Salvador (Figure 3). ${ }^{5}$ In El Salvador, one confidence index for the investment climate has been in negative territory since the GFC. Business confidence did not seem to have been affected by the GFC in the Dominican Republic (with one confidence index rebounding after a sharp fall in December 2012 and September 2013 at the same level as before the GFC).

The literature highlights extensively the importance of changes in expectations in driving investment, but less so in Central America and mostly through uncertainty shocks, rather than confidence:

- $\quad$ Beaudry and Portier (2006) present properties of the joint behavior of total factor productivity (TFP) and stock prices, which highlight new challenges for the business cycle theory. They examine the correlation between innovations driving the long-run movements in TFP and innovations contemporaneously orthogonal to TFP. They find this correlation to be positive and almost equal

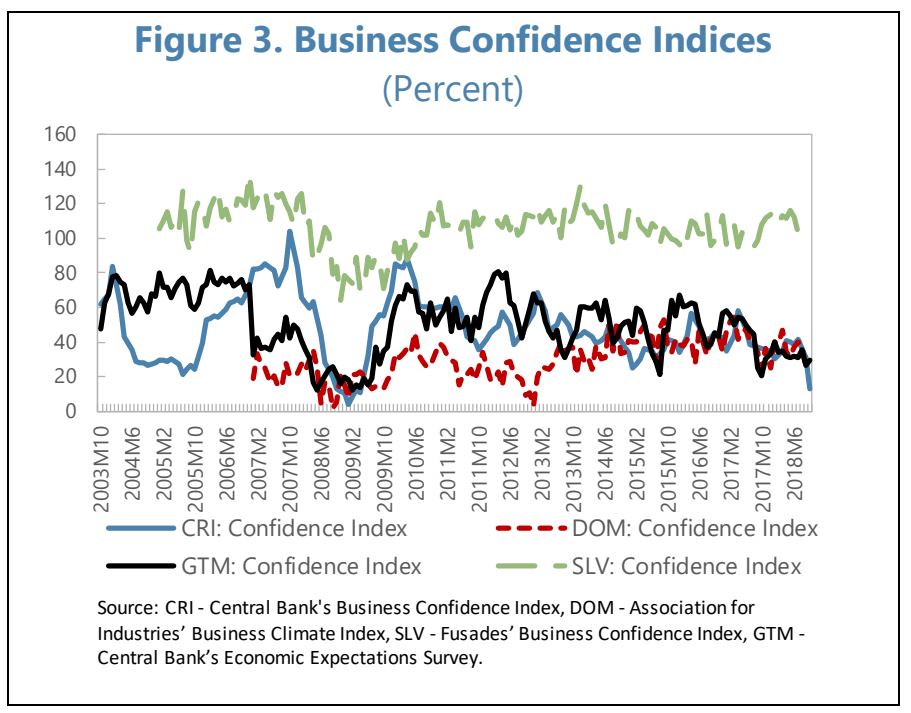
to one, indicating that permanent changes in productivity growth are preceded by stock market booms.

\footnotetext{
${ }^{4}$ This research does not include uncertainty as another investment driver due to data limitations. Since uncertainty can be approximated by measuring the degree of dispersion for a given amount of investment, cross sectional observations are required.

${ }^{5}$ The business confidence index likely captures changes in investors' perception of public finances performance and its overall impact on the economy.
} 
- $\quad$ Bloom (2009) offers a structural framework to analyze the impact of uncertainty shocks. The model contains a time-varying second moment, which is numerically solved and estimated using firm-level data; the model is then used to simulate a macro uncertainty shock, which produces a rapid drop and rebound in aggregate output and employment. The drop and rebound occur because higher uncertainty cause firms to temporarily pause their investment and hiring activities. Productivity growth also falls because this pause in activity freezes reallocation across units. In the medium term the increased volatility from the shock induces an overshoot in output, employment, and productivity. Thus, uncertainty shocks generate short but sharp recessions and recoveries.

- $\quad$ Carriere-Swallow and Cespedes (2011) examine to what extent the stylized facts reported in the literature on uncertainty shocks (i.e. generating sharp recessions and recoveries) are applicable to a heterogenous group of countries. They identify three findings about the impact of a global uncertainty shock: emerging markets suffer much more severe falls in investment and private consumption in comparison with developed economies, take significantly longer to recover, and do not experience a subsequent overshoot in activity.

- Albagli and Luttini (2015) provide micro (firm-level) evidence for Chile, showing that weak business confidence and uncertainty have a negative impact on investment, with uncertainty having a slightly lower impact. They use a VAR (Vector Autoregressive) model which analyzes the joint behavior of investment, global factors, domestic economic cycle, business confidence and uncertainty, and conclude that changes in investment are triggered both by macro shocks (global or domestic) as well as autonomous changes in confidence; the latter becomes the relevant factor for investment.

- Sánchez-Fung (2009) discusses the determinants of investment for Costa Rica, El Salvador, Guatemala, Honduras, and the Dominican Republic. Over the long term, he finds investment cointegrating equations with real GDP growth and interest rates in each of the economies analyzed; over the short term, he finds a significant impact of real GDP growth on investment expansion. However, interest rates and uncertainty variables are found not to be significant in determining investment dynamics (only in the case of the Dominican Republic, a statistically significant negative relationship is found between uncertainty and investment).

In the rest of the paper, we examine the relevance of business confidence relative to other investment drivers and global shocks. The available evidence on the relevance of business confidence for countries in Central America is scant. We are unaware of any study analyzing the joint time-series behavior of a system representing the global activity, the domestic economy and investment drivers in Central America. We differ from Sánchez-Fung (2009) for example in that we take into account the contribution from global factors affecting investment in addition to domestic factors to gauge the impact of confidence on investment relative to other domestic and global factors, and we opted for a vector autoregressive model (VAR), which is well suited to capture the complex iterations between global conditions and domestic variables. 


\section{EMPIRICAL ANALYSIS}

\section{A. VAR Specification}

The analysis is conducted by using an unrestricted VAR model, where the $Y_{\text {th }}$ endogenous variable $\boldsymbol{Y}_{\boldsymbol{t}}^{\boldsymbol{c}}$ is defined as:

$$
Y_{t}^{c}=\phi_{0}^{c}+\sum_{h=1}^{q} \sum_{i=1}^{p} \phi_{i}^{h} Y_{t-i}^{h}+\sum_{f=1}^{s} \sum_{i=0}^{r} \omega_{i}^{f} X_{t-i}^{f}+\varepsilon_{t}^{c}
$$

$\mathrm{c}=1,2, \ldots \mathrm{q}$, where $\mathrm{q}$ is equal to the number of endogenous variables; $\mathrm{p}$ represents the number of lags of the endogenous variables; $\mathrm{s}$ is equal to the number of exogenous variables; $r$ is the number of lags of the exogenous variables.

$Y_{t}^{c}, X_{t}^{c}, \phi_{0}^{c}, \phi_{i}^{c}, \omega_{i}^{c}$ and $\varepsilon_{t}^{c}$ respectively denote the endogenous variable, the exogenous variable, the constant, the autoregressive coefficients for the endogenous and exogenous variable, and the white noise error term. The exogenous block $X_{t}^{c}$ incorporates the small open economy assumption — standard in the VAR literature - whereby foreign variables do not respond to changes in domestic variables.

$$
Y_{t}^{c}=\left\{i n v_{t}, t p m_{t}, c i_{t}, u l c_{t}, g d p_{t}\right\}
$$

$i n v_{t}, t p m_{t}, c i_{t}, u l c_{t}$, and $g d p_{t}$ denote: the log of private investment, the log of one plus lending rates, the log of the confidence index, the log of unit labor cost, and the log of GDP, respectively. The first variable in the list is the variable of interest, in our case investment (inv), the remaining variables are ordered from the most to the least exogenous since we are using a reduced VAR. The intuition behind using this set of variables is that the domestic policy rate influences investment through its effects on the cost of capital; confidence is relevant given the importance of perceptions of current economic conditions and investor expectations for the future; labor costs influence investment as they impact profitability of firms; and GDP is a key determinant of the expected rate of return to capital and is a proxy of the domestic business cycle. $X_{t}^{c}$ summarizes prevailing global economic and financial conditions:

$$
\text { global factors }=X_{t}^{c}=\left\{\text { gpmi }_{t}, w_{g d p_{t}}, \text { wip }_{t}, \text { oil }_{t}, f f r_{t}, \text { tre } 10_{t}, t s 10_{t}\right\}
$$

they denote the (log of) global purchasing managers' index, the (log of) world's GDP, the ( $\log$ of) world's industrial production, the (log of) crude oil prices, the log of one plus the federal funds rate, the (log of) one plus 10-year U.S. treasury bond, and the (log of) one plus 10 -year U.S. treasury bond plus the country's sovereign risk spread, respectively. ${ }^{6}$

\footnotetext{
${ }^{6}$ The fed funds rate and the 10-year U.S. treasury were also considered to see whether investment was more sensitive to short- or longer-term global rates. For the longer-term global rates two rates were tested: the 10-year U.S. treasury, summarizing the global financial conditions, and (ii) the 10-year U.S. treasury plus a sovereign risk spread, i.e., a measure of credit risk, which varies according to the country. Since global rates entered the regression equation one at a time, there was no risk of multi-collinearity in the regression results.
} 
All variables, either domestic or global, are in real terms. ${ }^{7}$ The $g p m i$, , wgdp , and wip $_{t}$ are used as proxies for changes in the global economy. ${ }^{8}$ Since the four economies in our sample are oil importers, changes in oil $_{t}$ might have a significant impact on investment decisions, as electricity is an intermediary input in the manufacturing and the maquila sectors, and oil prices might also embody changes in other global factors, which themselves have an impact on investment inflows. ${ }^{9}$ The $f f r_{t}$, the tre $10_{t}$ and the $t s 10_{t}$ are included since changes in the U.S. monetary policy have significant implications for capital flows worldwide as well as changes in the sovereign risk for the country in question. ${ }^{10}$

The variables used in the analysis are all I(1). When the VAR was estimated using monthly data with 4, 6, or 8 lags, the lag length test (Hannan-Quinn Information Criteria, HQ) suggested that 2 lags would be appropriate for all countries. With the results of the unrestricted VAR, we also tested for cointegration using the Johansen's Unrestricted Cointegration Rank Test (Trace) at the 0.05 level; we found two cointegrating equations for Costa Rica and Guatemala; and one for the Dominican Republic and El Salvador.

We estimate a VECM (Vector Error Correction Model). Since the variables used in our analysis are non-stationary but all are I(1) and are cointegrated, we can run a restricted VAR, i.e., a vector error correction model, VECM to reconcile the long-run equilibrium with outof-equilibrium behavior over the short run and identify the long-run and short-run relationship of the variables. An error correction model for the $Y_{t h}$ endogenous variable $\Delta \boldsymbol{Y}_{\boldsymbol{t}}^{\boldsymbol{c}}$ and up to $u$ cointegrating equations, is specified as follows:

$$
\Delta Y_{t}^{c}=\beta_{0}^{c}+\sum_{h=1}^{q} \sum_{i=1}^{p-1} \beta_{i}^{h} \Delta Y_{t-i}^{h}+\sum_{f=1}^{s} \sum_{i=0}^{r} \omega_{i}^{f} X_{t-i}^{f}+\sum_{j=1}^{u} \phi_{c}^{j} Z_{t-1}^{j}+\mu_{t}^{c}
$$

\footnotetext{
${ }^{7}$ Therefore, even though the nominal fed funds rate was nearly zero in the years after the GFC, in real terms, it showed a high degree of variation. The U.S. CPI change over the last 12 months was used to deflate the global interest rate series as well as oil prices.

${ }^{8} \mathrm{The}_{\mathrm{gpmi}}$ and the wip $_{t}$ are series with monthly frequency, expressed as indexes in real terms, seasonally adjusted. The $w g d p_{t}$ series has quarterly frequency, expressed as a rate of real growth (year over year), this series was converted into an index and then extrapolated into monthly frequency. The source for the first two series was the Netherlands Bureau for Economic Policy Analysis (CPB, in its Dutch acronym). The WEO Database was the source for the World GDP series.

${ }^{9}$ The Western Hemisphere Regional Economic Outlook's chapter on "Drivers of Capital Flows and the Role of the Investor Base in Latin America" (April 2017) finds that commodity prices were strongly related to the global financial cycle from 2000 onward, and investment decisions in Latin America appeared to be influenced by commodity prices in both commodity and non-commodity producing sectors.

${ }^{10}$ The sovereign risk was approximated by using the country's risk spread of the EMBI+ Latam for the Dominican Republic and El Salvador. The sovereign-spread time series for Costa Rica and Guatemala are only available as of mid-2012, the Latin America's spread was used to gap filled these series from the mid-2000s through mid-2012. The Western Hemisphere Regional Economic Outlook's chapter on "Drivers of Capital Flows and the Role of the Investor Base in Latin America" (April 2017) finds that results of their analysis are broadly the same when U.S. short-term vs. long-term rates are included in the regression.
} 
Where $Y_{t}^{c}$ and $X_{t}^{c}$ are those as defined in (1), $Z_{t-1}^{j}$ is the error correction term (ECT), which is defined as the OLS residual of the following long-term cointegrating regression:

$$
Y_{t-1}^{j}=\lambda_{0}^{j}+\sum_{h=1}^{q-1} \lambda_{h}^{j} Y_{t-1}^{1+h}
$$

Where $\mathrm{j}=1$ or 2 (i.e., at most two cointegrating equations). When $\mathrm{j}=2$, then $\lambda_{1}^{1}=\lambda_{1}^{2}=0$. Note that if a VAR has $p$ lags, its VECM will have $p$ - 1 lags.

Using (5), ECT is defined as:

$$
Z_{t-1}^{j}=E C T_{t-1}^{j}=Y_{t-1}^{j}-\lambda_{0}^{j}-\sum_{h=1}^{q-1} \lambda_{h}^{j} Y_{t-1}^{1+h}
$$

ECT represents the long-term adjustment but it also affects the short-term dynamics; when there is a shock, for the system to return to equilibrium, the parameter of ECT $(\phi)$ in (4) must be negative.

Applying equations (1), (4) and (6) to the case at stake, where inv denotes private investment, and we use 2 lags, 2 cointegrating equations, and 1 exogenous variable, the VAR takes the form:

$$
\begin{gathered}
i n v_{t}=\beta_{0}^{i n v}+\beta_{1}^{i n v} i n v_{t-1}+\beta_{2}^{i n v} i n v_{t-2}+\beta_{1}^{t p m} t p m_{t-1}+\beta_{2}^{t p m} t p m_{t-1}+\beta_{1}^{c i} c i_{t-1}+ \\
+\beta_{2}^{c i} c i_{t-2}+\beta_{1}^{u l c} u l c_{t-1}+\beta_{2}^{u l c} u l c_{t-2}+\beta_{1}^{g d p} g d p_{t-1}+\beta_{2}^{g d p} g d p_{t-2}++\omega_{0} \text { global }_{t}+ \\
+\mu_{t}^{i n v}(7)
\end{gathered}
$$

Our VECM and ECTs for the variable of interest (inv) are:

$$
\begin{gathered}
\Delta i n v_{t}=\beta_{0}^{i n v}+\beta_{1}^{i n v} \Delta i n v_{t-1}+\beta_{1}^{t p m} \Delta t p m_{t-1}+\beta_{1}^{c i} \Delta c i_{t-1}+\beta_{1}^{u l c} \Delta u l c_{t-1} \\
+\beta_{1}^{g d p} \Delta g d p_{t-1}+\phi_{i n v}^{i n v} Z_{t-1}^{i n v}+\phi_{i n v}^{t p m} Z_{t-1}^{t p m}+\omega_{0} g l o b a l_{t}+\mu_{t}^{i n v} \\
Z_{t-1}^{i n v}=E C T_{t-1}^{i n v}=i n v_{t-1}-\lambda_{0}^{i n v}-\lambda_{2}^{i n v} c i_{t-1}-\lambda_{3}^{i n v} u l c_{t-1}-\lambda_{4}^{i n v} g d p_{t-1} \\
Z_{t-1}^{t p m}=E C T_{t-1}^{t p m}=t p m_{t-1}-\lambda_{0}^{t p m}-\lambda_{2}^{t p m} c i_{t-1}-\lambda_{3}^{t p m} u l c_{t-1}-\lambda_{4}^{t p m} g d p_{t-1}
\end{gathered}
$$

In sum, the change in investment (8) responds to the adjustment towards its long-term equilibrium (represented by the lag of the dependent variable); changes in variables that affect investment (tpm, ci, ulc and gdp) with a lag; it is also affected by the global economic and financial conditions (exogenous variable). Since investment has a long-run equilibrium path according to (6), a fraction of the deviations from this long-term path is corrected in 
each period. Thus, changes of investment today represent a combination of short and longterm factors. ${ }^{11}$

\section{B. Data Used}

The dataset spans roughly between eleven and fifteen years of monthly observations, until June 2018. In particular, it includes data from March 2003 for Costa Rica, March 2007 for the Dominican Republic, and March 2005 to June 2018 for El Salvador and Guatemala (184, 136,160 observations, respectively). ${ }^{12}$ For those series which were available only on a quarterly frequency (private gross fixed capital formation, inv, unit labor cost, ulc, world's GDP and confidence index), the quarterly data were interpolated into monthly series. ${ }^{13}$

All series used in the analysis are in real terms and are seasonally adjusted. The Census X-13 procedure was used in those cases where the raw series were unavailable in seasonally adjusted form. To measure confidence, we use Business Confidence Indices based on surveys of business conditions and expectations in each of the countries studied. These indices are forward looking, where the confidence index measures perceptions of recent economic activity (see Table 2 and Annex I for more details for each country).

- In Costa Rica, the index measures expectations of the business climate as well as perceptions of current economic conditions.

- In the Dominican Republic, expectations about the global economy, the investment climate, business conditions and overall activity of the sector in which businesses operated form the basis of the index.

- In El Salvador, the confidence index is constructed based on perceptions of current economic conditions, as well as expectations of investment volumes and evolution of business conditions.

- In Guatemala, the index measures expectations of the business climate and overall economic performance, as well as perceptions of current economic conditions compared to a year earlier.

Despite methodological differences, confidence indices are roughly comparable, with similar samples, survey design, questions asked, etc.

\footnotetext{
${ }^{11}$ In our model structural factors, such as the business climate indicators (discussed above), affect investment, arguably, through their impact on confidence.

12 The starting date is defined by the shortest time series in each country and the number of lags used in the regression analysis (see Annex II: Methodological Notes - The VAR and the Number of Lags). In the case of Costa Rica, the departing point for the available number of observations was set by the availability of its confidence index series, which began in January 2003. For Guatemala, the starting point was set by its interest rate series - January 2005. For the Dominican Republic and El Salvador, the revision of their National Income Accounts with a new base year in 2007 and 2005, respectively, determined the starting point for their number of observations.

${ }^{13}$ See Annex II: Methodological Notes - Frequency of the Model.
} 
13

\begin{tabular}{|c|c|c|c|c|}
\hline Country & Index & Frequency & $\begin{array}{l}\text { Forward- } \\
\text { Looking }\end{array}$ & Measurement \\
\hline CRI & $\begin{array}{l}\text { Investment Confidence Index (Indice de } \\
\text { Confianza para la Inversion) }\end{array}$ & Quarterly & Yes & $\begin{array}{l}\text { Perception of investment climate, and } \\
\text { expectation of economic activity over the } \\
\text { next } 6 \text { months }\end{array}$ \\
\hline DOM & $\begin{array}{l}\text { Business Climate Index (Indice de Clima } \\
\text { Empresarial) }\end{array}$ & Quarterly & Yes & $\begin{array}{c}\text { Perception of investment climate, overall } \\
\text { economy, global economy, business and } \\
\text { overall sectoral activity }\end{array}$ \\
\hline SLV & $\begin{array}{l}\text { Business Confidence Index (Indice de } \\
\text { Confianza Empresarial) }\end{array}$ & Monthly & Yes & $\begin{array}{l}\text { Perception of current economic } \\
\text { conditions (net sales and business } \\
\text { activity), and expectations (investment } \\
\text { volume and expected evolution of } \\
\text { business conditions) }\end{array}$ \\
\hline GTM & $\begin{array}{c}\text { Economic Expectations Survey (Encuesta } \\
\text { de Expectativas Económicas) }\end{array}$ & Monthly & Yes & $\begin{array}{l}\text { Expectation of business climate and } \\
\text { economic performance over the next } 6 \\
\text { months, and perception of current } \\
\text { conditions for investment }\end{array}$ \\
\hline
\end{tabular}

To select between a restricted or unrestricted VAR, we determine the stationarity of the data by applying the augmented Dickey-Fuller (ADF) test. The specification of the ADF test is only with a constant and a trend term, no drift is used for all series tested. The results show that the series (log of) GDP, (log of) investment, (log of) confidence, (log of) one plus interest rate, (log of) index of unit labor cost series, do not reject the null hypothesis of having a unit root in the sample period at the usual 0.05 level (Table 3), i.e., all series considered likely are non-stationary: I(1). Since our series seem I(1), the selection of the model for empirical purposes (an unrestricted VAR or a restricted VAR, i.e., a VECM) depends on whether the series are cointegrated, something which we address in the following section. 
Table 3. Augmented Dickey-Fuller Unit Root Test Statistic with Constant and Trend ${ }^{1 /}$

(Seasonally Adjusted Figures)

\begin{tabular}{|c|c|c|c|c|c|c|c|c|c|c|c|c|}
\hline & \multicolumn{3}{|c|}{ Costa Rica } & \multicolumn{3}{|c|}{ Dominican Republic } & \multicolumn{3}{|c|}{ El Salvador } & \multicolumn{3}{|c|}{ Guatemala } \\
\hline & $\begin{array}{l}\text { ADF t- } \\
\text { Statistic }\end{array}$ & $p$-value & $\begin{array}{l}\text { Test } \\
\text { Result }\end{array}$ & $\begin{array}{l}\text { ADF t- } \\
\text { Statistic }\end{array}$ & $p$-value & $\begin{array}{l}\text { Test } \\
\text { Result }\end{array}$ & $\begin{array}{l}\text { ADF t- } \\
\text { Statistic }\end{array}$ & $p$-value & $\begin{array}{l}\text { Test } \\
\text { Result }\end{array}$ & $\begin{array}{l}\text { ADF t- } \\
\text { Statistic }\end{array}$ & $p$-value & $\begin{array}{l}\text { Test } \\
\text { Result }\end{array}$ \\
\hline Igdp & -1.70 & 0.75 & - & -1.35 & 0.87 & - & -2.21 & 0.48 & - & -2.79 & 0.20 & - \\
\hline dlgdp & -3.83 & 0.02 & $* *$ & -4.69 & 0.00 & $*$ & -4.35 & 0.00 & $*$ & -17.16 & 0.00 & $*$ \\
\hline Igfip & -2.45 & 0.35 & - & -1.38 & 0.86 & - & -2.17 & 0.51 & - & -1.83 & 0.69 & - \\
\hline dlgfip & -4.74 & 0.00 & $*$ & -6.65 & 0.00 & $*$ & -14.97 & 0.00 & $*$ & -14.57 & 0.00 & $*$ \\
\hline Ici & -2.69 & 0.24 & - & -3.39 & 0.06 & - & -2.82 & 0.19 & - & -2.42 & 0.37 & - \\
\hline dlci & -4.75 & 0.00 & $*$ & -16.19 & 0.00 & $*$ & -20.08 & 0.00 & $*$ & -16.88 & 0.00 & $*$ \\
\hline lulc & -2.46 & 0.35 & - & -2.94 & 0.16 & - & -3.20 & 0.09 & - & -1.20 & 0.91 & - \\
\hline dlulc & -10.26 & 0.00 & $*$ & -4.07 & 0.01 & $*$ & -14.61 & 0.00 & $*$ & -6.44 & 0.00 & $*$ \\
\hline $\mathrm{I}(1+\mathrm{tpm})$ & -2.43 & 0.36 & - & -3.27 & 0.08 & - & -2.95 & 0.15 & - & -2.81 & 0.20 & - \\
\hline $\mathrm{dl}(1+\mathrm{tpm})$ & -9.59 & 0.00 & $*$ & -8.74 & 0.00 & $*$ & -9.77 & 0.00 & $*$ & -7.57 & 0.00 & $*$ \\
\hline \multicolumn{4}{|c|}{ Global Variables } & & & & \multicolumn{6}{|c|}{ Nomenclature } \\
\hline Igpmi & -2.97 & 0.14 & - & & & & gfip & \multicolumn{5}{|c|}{ private gross fixed investment } \\
\hline dlgpmi & -14.35 & 0.00 & $*$ & & & & tpm & \multicolumn{5}{|c|}{ interest rate } \\
\hline Iwgdp & -1.93 & 0.20 & - & & & & ci & \multicolumn{5}{|c|}{ confidence index } \\
\hline dlwgdp & -6.10 & 0.00 & $*$ & & & & ulc & \multicolumn{5}{|c|}{ unit labor cost } \\
\hline Iwip & -3.35 & 0.06 & - & & & & gdp & \multicolumn{5}{|c|}{ gross domestic product } \\
\hline dlwip & -5.96 & 0.00 & $*$ & & & & gpmi & \multicolumn{5}{|c|}{ global manufacturing PMI } \\
\hline loil & -1.97 & 0.61 & - & & & & wgdp & \multicolumn{5}{|c|}{ world gross domestic product } \\
\hline dloil & -12.10 & 0.00 & $*$ & & & & $\begin{array}{l}\text { wip } \\
\text { oil }\end{array}$ & \multicolumn{5}{|c|}{$\begin{array}{l}\text { world industrial production } \\
\text { international oil price }\end{array}$} \\
\hline $\mathrm{I}(1+\mathrm{ffr})$ & -3.52 & 0.04 & $*$ & & & & ffr & \multicolumn{5}{|c|}{ federal funds rate } \\
\hline $\mathrm{dl}(1+\mathrm{ffr})$ & -10.19 & 0.00 & $*$ & & & & tre10 & \multicolumn{5}{|c|}{ 10-year U.S. treasury bond yield } \\
\hline $\mathrm{I}(1+\operatorname{tre} 10)$ & -4.23 & 0.00 & $*$ & & & & ts10 & \multicolumn{5}{|l|}{ 10-year U.S. } \\
\hline $\mathrm{dl}(1+\operatorname{tre} 10)$ & -11.05 & 0.00 & $*$ & & & & & \multicolumn{5}{|l|}{ spread } \\
\hline $\mathrm{I}(1+\mathrm{ts} 10)$ & -3.90 & 0.00 & $*$ & & & & Ivar & \multicolumn{5}{|c|}{ log of "var" } \\
\hline $\mathrm{dl}(1+\mathrm{ts} 10)$ & -11.06 & 0.00 & $*$ & & & & dlvar & \multicolumn{5}{|c|}{ first difference of Ivar } \\
\hline \multicolumn{13}{|c|}{ Number of Observations } \\
\hline CRI & \multirow{2}{*}{\multicolumn{6}{|c|}{$\begin{array}{l}2003-03 \text { to } 2018-06 \text { (184 monthly observa DOM } \\
200503 \text { to } 201806 \text { ( } 160 \text { monthly observat GTM }\end{array}$}} & DOM & \multirow{2}{*}{\multicolumn{5}{|c|}{$\begin{array}{l}2007-03 \text { to } 2018-06 \text { ( } 136 \text { monthly observations). } \\
200503 \text { to } 201806 \text { ( } 160 \text { monthly observations). }\end{array}$}} \\
\hline SLV & & & & & & & GTM & & & & & \\
\hline 1/ & \multirow{2}{*}{\multicolumn{6}{|c|}{$\begin{array}{l}\text { Ho: Series has a unit root at the } 0.05 \text { level. } \\
\text { Could Not Reject Ho }\end{array}$}} & $*$ & \multicolumn{5}{|c|}{ Reject Ho at 0.01 level } \\
\hline- & & & & & & & $* *$ & \multicolumn{5}{|c|}{ Reject $\mathrm{Ho}$ at 0.05 level } \\
\hline
\end{tabular}

Source: IMF staff estimates.

\section{Estimation Results}

Within the traditional investment drivers, a confidence shock is, on average, the most important driver in explaining the composition of investment residuals-exceeded only by global factors - followed, thereafter, by interest rates, GDP and unit labor costs (Table 4).

- The contribution of confidence accounted for over one sixth of the total, and was particularly stronger in the lower-middle income CAPDR countries (El Salvador and 
Guatemala), ${ }^{14}$ explaining, on average, one fourth of the investment residuals, while the upper-middle income CAPDR countries (Costa Rica and the Dominican Republic) contributed with a bit less than one tenth.

- With slightly more than one fifth of the total contributions, global factors were the largest contributor. But its distribution across countries was far from uniform, while the contribution of Costa Rica and the Dominican Republic was well above the average, Guatemala and El Salvador were exactly on the opposite side.

- The contribution of confidence is stronger for the lower-middle income CAPDR countries, while the contribution of global factors is stronger for the upper-middle income CAPDR countries; one possible interpretation of this outcome is that as economic development takes root, countries start relying more on global factors (i.e., they become more integrated with the global economy). ${ }^{15}$

- The contribution of interest rates was much higher than that for confidence for the upper-middle income CAPDR countries. Unlike for El Salvador, where it was significantly lower than the contribution of confidence. Perhaps, in a dollarized economy (like El Salvador), investment might become less sensitive to interest rates.

- The contributions of unit labor costs and GDP were the lowest of the group; the countries' distribution of unit labor costs suggests that as the economies develop further, their sensitivity to unit labor costs increases (perhaps due to labor becoming less abundant).

\footnotetext{
${ }^{14}$ Guatemala was classified as lower-middle income economy until 2017, just half a year before our sample of thirteen and half years ended.

${ }^{15}$ To reflect the impact of global economic conditions, four indicators were considered: global purchasing managers' index $\left(g p m i_{t}\right)$, world's GDP $\left(w g d p_{t}\right)$, world's industrial production $\left(w i p_{t}\right)$ and oil prices. To reflect global financial conditions: the fed funds rate $\left(f f r_{t}\right)$, the 10-year U.S. treasury bond yield (tre $\left.10_{t}\right)$, and the 10year U.S. treasury bond yield plus a sovereign risk spread $\left(\mathrm{ts} 10_{t}\right)$, were tested. Two criteria guided us in the selection of the final combination of global shocks: parsimony, given the limited number of observations in our sample, and any exogenous variable to be selected should help minimize the sum of unexplained square errors of the equation under estimation.
} 


\begin{tabular}{|c|c|c|c|c|c|c|c|}
\hline \multicolumn{8}{|c|}{$\begin{array}{l}\text { Table 4. Contributions to Investment Residuals-Baseline } \\
\text { (Percent) }\end{array}$} \\
\hline & global 1/ & inv & tpm & $c i$ & ulc & $g d p$ & Total \\
\hline CRI & 27.6 & 24.8 & 23.8 & 14.7 & 2.8 & 6.3 & 100.0 \\
\hline DOM & 16.6 & 63.0 & 10.0 & 4.8 & 5.0 & 0.6 & 100.0 \\
\hline GTM & 31.0 & 31.6 & 18.3 & 16.0 & 2.4 & 0.8 & 100.0 \\
\hline SLV & 5.1 & 37.6 & 8.8 & 34.2 & 2.3 & 12.0 & 100.0 \\
\hline Baseline & 20.1 & 39.2 & 15.2 & 17.4 & 3.1 & 4.9 & 100.0 \\
\hline \multicolumn{8}{|c|}{$\begin{array}{l}\text { 1/ Global variables include World GDP, 10-year U.S. Treasury Bond Yield, 10-year U.S. Treasury Yield } \\
\text { plus a Sovereign Risk Spread. }\end{array}$} \\
\hline
\end{tabular}

- The root mean square error (RMSE) and the adjusted $\mathrm{R}^{2}$ suggest that the Costa Rica's data fits the model better than its peers; it has the lowest RMSE and the highest adjusted R2 (text table). Annex III shows the historical decomposition of the investment residual in a graphical representation for our sample. Had the fitting been perfect, the investment residual (red bold line) would have been on top (in case of a positive error) or at bottom (for a negative one) of its components.

\begin{tabular}{lrr} 
& RMSE & Adj. R2 \\
CRI & 0.0811 & 0.3315 \\
DOM & 0.0882 & 0.2802 \\
SLV & 0.0986 & 0.0597 \\
GTM & 0.1138 & 0.0409 \\
\hline
\end{tabular}

Costa Rica clearly shows the best graphical adjustment among its peers.

- A few residual diagnostic tests were carried out on the model (Table 5). For all countries, the null hypothesis of no serial correlation could not be rejected. ${ }^{16}$ The CUSUM test for stability of the model parameters was passed in all cases at the 0.05 level. Finally, the null hypothesis of no heteroskedasticity could not be rejected at the 0.05 level for Costa Rica, El Salvador, and Guatemala, and at the 0.025 level for the Dominican Republic.

\footnotetext{
${ }^{16}$ With serial correlation, the estimated parameters still converge to their true value, but they are not efficient, i.e., do not have minimum variance and, thus, a variety of tests are no longer valid ( $\mathrm{t}, \mathrm{F}, \mathrm{Chi}$ Square).
} 


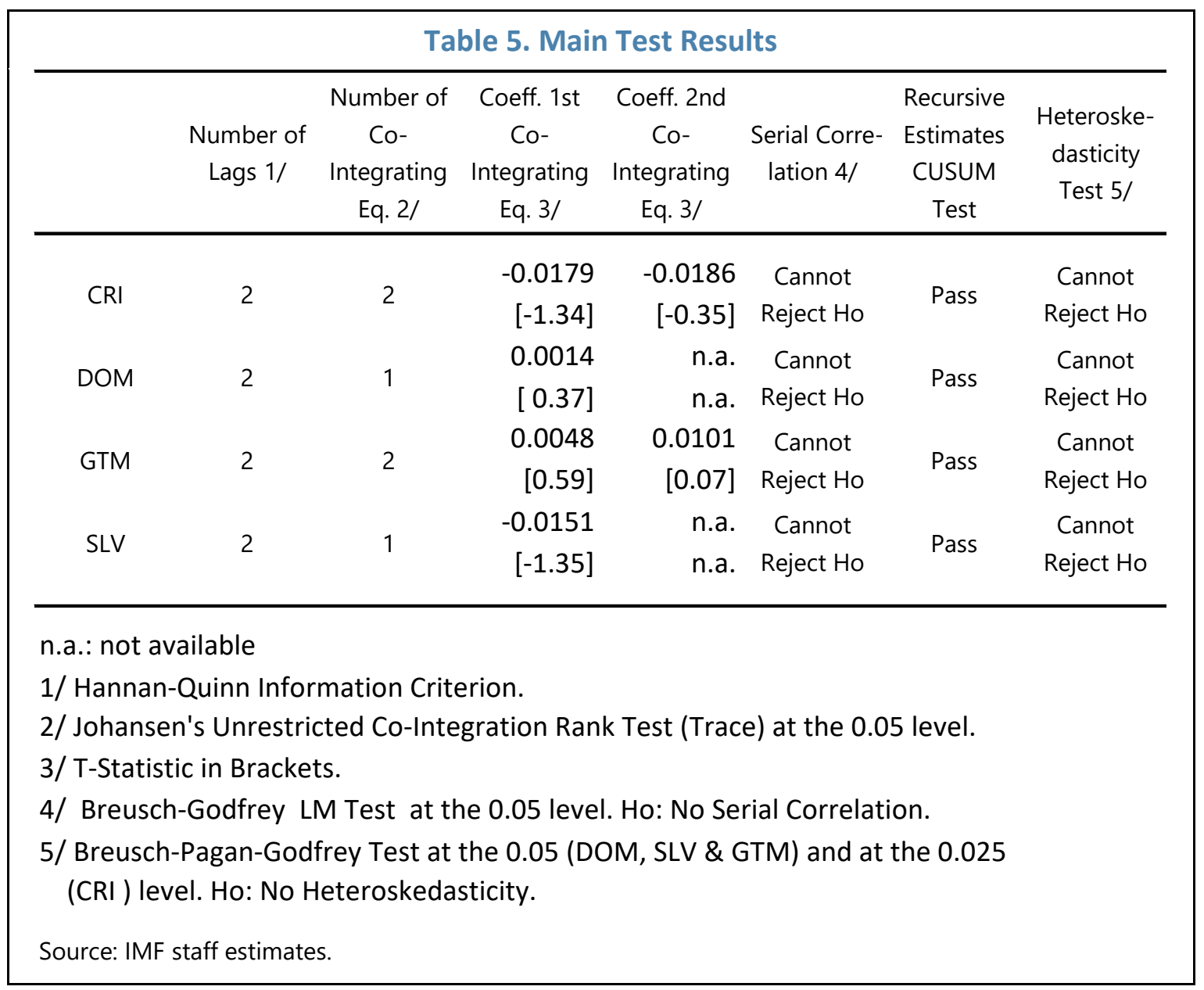

- Per our discussion above on our time series likely being non-stationary, and the results of the Johansen's Unrestricted Co-Integration Rank test (Costa Rica and Guatemala have two co-integrating factors, while the Dominican Republic and El Salvador have one), a VECM was selected as the model for empirical purposes.

- The coefficients of the error correction terms (a.k.a. as the speed of adjustment coefficients): $\phi_{i n v}^{i n v}$ and $\phi_{i n v}^{t p m}$ must be negative, such that following a shock, investment will eventually converge to its long-run equilibrium by a combination of long- and short-term dynamics. ${ }^{17}$ But the estimated coefficients are not significant.

\footnotetext{
${ }^{17}$ Please see Annex II. Some Methodological Notes pertaining to the data: From Quarterly to Monthly Frequency; Non-Seasonally Adjusted Series (NSAS) versus Seasonally Adjusted Series (SAS); Estimating the Impact of Changes in the Exogenous Variables in a VAR, as well as Estimating the Contributions of Structural Shocks. Annex III presents graphically the estimated contributions coming from global shocks and investment drivers for the countries in our sample.
} 


\section{Impulse Response Functions (IRFs)}

They show how a variable of interest (investment in our case) responds, for a given period of time, to shocks in other variables (called impulses); the calculations are based on the underlying VECM, and the results could be shown as they are estimated (called responses; our case) or as the cumulative value of these individual results overtime. ${ }^{18}$ Figure 4 shows the changes of investment to changes (one standard deviation) in its drivers, which could be thought of as elasticities of investment to its drivers.

- The impulses of confidence have a positive impact on inv with varying intensities across countries (Figure 4). The strongest impact over the long term is in El Salvador, followed by Guatemala, Costa Rica and the Dominican Republic, which is consistent with the results shown in Table 4. In the case of Costa Rica, the impact increases overtime until it stabilizes - after more than a year or so; it then declines until it finally stabilizes after roughly two years.

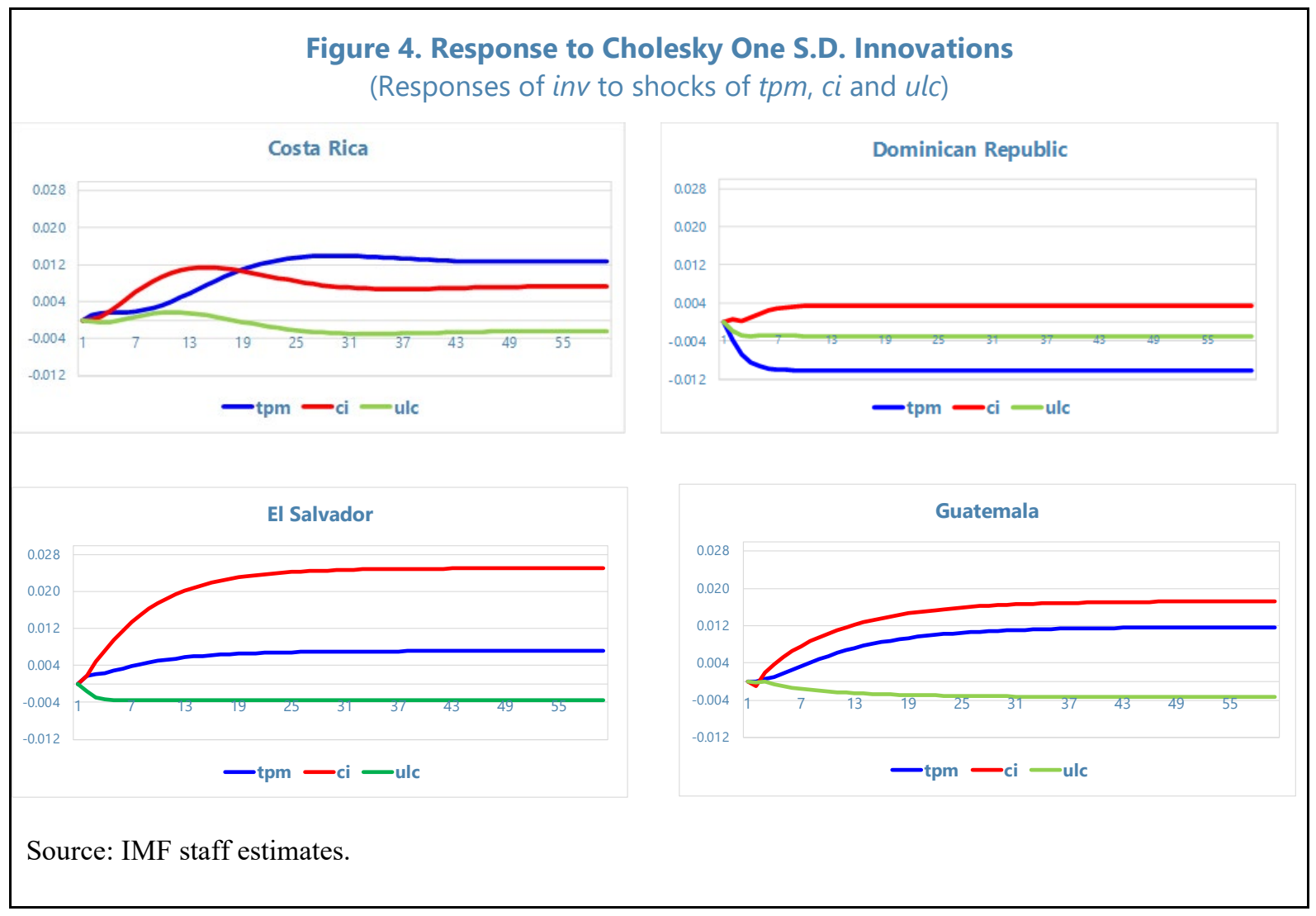

- The investment response to a shock of one standard deviation of the interest rate, tpm, is negative (as expected) only for the Dominican Republic. For Costa Rica, El Salvador and Guatemala, the impact is positive over the long term. Thus, unlike $c i$, the impact of a tpm shock varies depending on the country.

\footnotetext{
${ }^{18}$ Individual charts in Figure 4 have the same scale.
} 
- In the case of $u l c$, the impact is negative, as expected, for the four countries. In Costa Rica, the response is initially positive but over time it becomes negative. It seems counter-intuitive that as ulc rises, investment increases as well. But in the case of Costa Rica, a fraction of the labor force is highly qualified and even though these workers are expensive, their value added is expensive too; increases in labor costs still yield a favorable (but declining) net outcome for this group, while the impact of higher labor costs in the remaining labor force is outright negative. Since the former group is of limited size, their positive impact is overcome, at some point, by the negative one of the remaining (larger) group.

\section{E. Sensitivity Analysis}

Sensitivity analysis to a different ordering of the variables in the Cholesky decomposition was conducted to explore whether the ordering of the variables affected the estimated parameters. To assess whether different ordering of the variables will have a significant impact on our estimated results, two alternative modifications in the orderings are used:

$$
\begin{aligned}
Y_{t}^{c} & =\left\{i n v_{t}, t p m_{t}, u l c, c i_{t}, g d p_{t}\right\} \\
Y_{t}^{c} & =\left\{i n v_{t}, g d p_{t}, t p m_{t}, u l c_{t}, c i_{t}\right\}
\end{aligned}
$$

where the positions of $c i$ and $u l c$ in (11) and the positions of $g d p, t p m, u l c$ and $c i$ in (12) have changed when compared to (2). The first modification is just a minor one whereby the positions of $c i$ and $u l c$ in (2) have been swapped. The second alternative represents a more stringent modification, whereby three variables have a differing ordering and their degree of endogeneity is also altered.

- Table 6 shows that the different ordering brings about just a marginal realignment in the composition of the contributions (particularly of global factors and confidence). However, the relative contributions to explain the investment residuals remain basically unchanged, i.e., the top contributors continue to be global factors and confidence.

- Table 7 shows that when we swapped three variables, confidence continues to be the domestic driver with the largest contribution. However, global factors take the lead overall. In sum, sensitivity analysis suggests that confidence and global shocks are the largest contributors of the investment residual under alternative ordering of the parameters. 


\begin{tabular}{|cccccccc|}
\hline \multicolumn{7}{|c|}{ Table 6. Contributions to Investment Residuals - Alternative 1 } \\
\multicolumn{7}{c}{ (Percent) } \\
\hline global 1/ & inv & tpm & ulc & $c i$ & gdp & Total \\
\hline CRI & 25.1 & 25.7 & 23.9 & 3.5 & 15.4 & 6.3 & $\mathbf{1 0 0 . 0}$ \\
DOM & 14.4 & 64.6 & 9.9 & 7.0 & 3.5 & 0.6 & $\mathbf{1 0 0 . 0}$ \\
GTM & 31.3 & 37.7 & 18.4 & 2.0 & 15.8 & 0.8 & $\mathbf{1 0 0 . 0}$ \\
SLV & 8.2 & 37.4 & 9.1 & 1.9 & 30.7 & 12.8 & $\mathbf{1 0 0 . 0}$ \\
(i) Alternative 1 & $\mathbf{1 9 . 7}$ & $\mathbf{3 9 . 9}$ & $\mathbf{1 5 . 3}$ & $\mathbf{3 . 6}$ & $\mathbf{1 6 . 3}$ & $\mathbf{5 . 1}$ & $\mathbf{1 0 0 . 0}$ \\
(ii) Baseline & $\mathbf{2 0 . 1}$ & $\mathbf{3 9 . 2}$ & $\mathbf{1 5 . 2}$ & $\mathbf{3 . 1}$ & $\mathbf{1 7 . 4}$ & $\mathbf{4 . 9}$ & $\mathbf{1 0 0 . 0}$ \\
(i) - (ii) & $\mathbf{- 0 . 3}$ & $\mathbf{0 . 6}$ & $\mathbf{0 . 1}$ & $\mathbf{0 . 5}$ & $\mathbf{- 1 . 1}$ & $\mathbf{0 . 2}$ & $\mathbf{0 . 0}$ \\
\hline 1/ Global variables include World GDP, 10-year U.S. Treasury Bond Yield, 10-year U.S. Treasury Yield & \\
plus a Sovereign Risk Spread. \\
Source: IMF staff estimates.
\end{tabular}

\begin{tabular}{|c|c|c|c|c|c|c|c|}
\hline & le 7. Cor & ution: & $\begin{array}{l}\text { nvest } \\
\text { (Perc }\end{array}$ & Resi & Alte & & \\
\hline & global 1/ & inv & $g d p$ & tpm & ulc & $c i$ & Total \\
\hline CRI & 16.7 & 29.0 & 15.0 & 25.3 & 3.0 & 11.0 & 100.0 \\
\hline DOM & 14.6 & 64.3 & 0.9 & 9.3 & 7.2 & 3.6 & 100.0 \\
\hline GTM & 31.5 & 32.0 & 1.0 & 18.2 & 1.6 & 15.7 & 100.0 \\
\hline SLV & 4.7 & 39.4 & 14.9 & 3.2 & 3.6 & 34.1 & 100.0 \\
\hline (i) Alternative 2 & 16.9 & 41.2 & 8.0 & 14.0 & 3.8 & 16.1 & 100.0 \\
\hline (ii) Baseline & 20.1 & 39.2 & 4.9 & 15.2 & 3.1 & 17.4 & 100.0 \\
\hline (i) - (ii) & -3.2 & 1.9 & 3.0 & -1.2 & 0.7 & -1.3 & 0.0 \\
\hline \multicolumn{8}{|c|}{$\begin{array}{l}\text { 1/ Global variables include World GDP, 10-year U.S. Treasury Bond Yield, 10-year U.S. Treasury Yield } \\
\text { plus a Sovereign Risk Spread. }\end{array}$} \\
\hline \multicolumn{8}{|c|}{ Source: IMF staff estimates. } \\
\hline
\end{tabular}

\section{CONCLUding ReMARKS}

This paper has aimed to gauge the relevance of business confidence over recent years, relative to other traditional investment drivers and global shocks by using a vector error correction model in four Central American countries. The results suggest that global shocks and confidence are the most important drivers in explaining private investment: on average, confidence shocks accounted for over one sixth of the investment residuals (about one tenth in the upper middle-income economies of Costa Rica and the Dominican Republic and one 
fourth in the northern triangle countries of El Salvador and Guatemala). The contribution of interest rates came in the third position, while GDP and unit labor costs shocks contribution occupied the fourth and fifth places.

- From our analysis between upper-middle income and lower-middle income economies, it appears that for the latter group, confidence followed by global factors are the leading drivers of investment. But as economic development takes hold, and the economies become more integrated to the global economy, global shocks might become the leading driver. Domestic shocks do not seem to be driving long-run investment as higher uncertainty cause firms to only temporarily pause their investment and hiring activities, leading to a sharp drop and a rebound in aggregate output and employment, as found by Bloom (2009). At the same time, global uncertainty shocks lead to more severe falls in investment and private consumption in emerging markets in comparison with developed economies, and take significantly longer to recover, in line with Carriere-Swallow and Cespedes (2011).

- Our analysis shows that an impulse of confidence (IRFs) has a positive impact in the four countries of our sample over the long term.

- Two alternative orderings of the explanatory variables were carried out to analyze the sensitivity of the estimated parameters (and their impact on the composition of the investment residuals). The changes in the Alternative 1 scenario were negligible, while in the Alternative 2 scenario the changes limited mainly to a small reduction of global factors in favor of GDP. Global shocks and confidence remain the top contributors under either alternative scenario.

- Unlike global shocks, confidence can be influenced by policymakers' decisions and, thus, based on our results, reforms to improve confidence play an important role in promoting investment, and, thereby, economic growth. Following the Ease of Doing Business indicators, reforms required to boost confidence should aim to improve the business environment, product and labor markets, and governance.

- Policymakers in charge of improving business conditions should consider how the global rankings are determined and what conditions and requirements are necessary in a business category to meet a minimum global standard. To raise private investment durably, it will be critical to improve business environment conditions, by reducing barriers to competition and making product markets more efficient, enhance the quality and efficiency of the education system, modernize labor markets, and keep wages in line with productivity (El Salvador and the Dominican Republic), facilitate trade and reduce burdensome regulations (Costa Rica, the Dominican Republic and El Salvador), increase the efficiency of the tax system (the Dominican Republic and El Salvador), and reduce crime (El Salvador and Guatemala). In Guatemala, efforts are needed to implement an integral fiscal reform encompassing continued tax administration efforts, tax policy changes, and spending flexibility. In all countries, further reductions in the cost of credit by strengthening the legal framework and credit reporting system remain essential. Last, but not least, sustained efforts to improve governance and government effectiveness, including implementing transparent and fair procurement laws and 
processes to ensure that public resources are spent wisely and that all firms have the opportunity to compete fairly for the contracts, are critical to durably raise investment. 


\section{ANNEX I: BuSINESS CONFIDENCE INDICES In COSTA RiCA, DoMiniCAN REPUbLIC, El SALVAdor, AND GUatemala}

In the four countries, we use different indices to measure confidence:

- $\quad$ For Costa Rica, we use the Central Bank's Business Confidence Index. The Business Confidence Index-Indice de Confianza para la Inversion is based on a quarterly survey of academics, consultants, and businesses, and captures perceptions of the investment climate, and expectations of economic activity in the next six months compared to the last six months. A value is assigned to each answer with respect to the investment climate and expectations of overall economy (for perceptions of investment climate, bad: 0, uncertain: 50, good: 100, and for expectations of overall economic activity, worse: 0 , equal: 50, better: 100 ), and the weighted average of answers in these two areas surveyed is calculated.

- In the case of the Dominican Republic, we use the Association for Industries' Business Climate Index. The index - Indice de Clima Empresarial is based on a quarterly business survey, La Encuesta de Coyuntura Industrial (State of Industry Survey) by the Association of Industries and measures business perception of the investment climate and overall economy, the global economy, the business situation of each enterprise surveyed and of the overall sector in which the enterprise operates. The business climate index is derived by creating sub-indexes based on perceptions businesses hold, i.e. whether they are optimistic regarding the questions/issues noted above.

- $\quad$ For El Salvador, we use Fusades' Business Confidence Index. The monthly confidence index - Indice de Confianza Empresarial is based on the answers to two questions of the monthly business survey by think-tank Fusades, and its calculation is derived by creating sub-indexes of each of the questions. The confidence index is constructed, on the one hand, from a perception index of current economic conditions, and on the other hand, from an expectations index, equally weighted in the overall index. The perception index is constructed based on two other subindexes, equally weighted as well, i.e. net sales (businesses who say they sold more, minus those who say they sold less than in the previous period) and the recent evolution of business activity. The expectation index is constructed based on two other sub-indexes as well, equally weighted, i.e. investment volume (if businesses have effectively invested) and the expected evolution of business conditions. The overall confidence index is the average of the sub-indexes, expressed as a percent of the maximum possible average.

- In the case of Guatemala, we use the Central Bank's Economic Expectations Survey. The monthly confidence index is based on the answers to four questions of the Central Bank's survey, Encuesta de Expectativas Económicas (Economic Expectations Survey), and its calculation is derived by creating sub-indexes for each of the questions. The four questions are: (i) "How do you think the business climate for private sector's economic activity will evolve over the next six months compared with the previous six months?", (ii) "Do you agree the economy is in better shape 
than a year ago?", (iii) "Do you expect the country's economic performance to improve over the next six months?", and (iv) "What do you think of the present moment for companies to carry out investments?". The sub-indexes are constructed by subtracting from the percentage of positive answers, the percentage of negative answers and adding 100 to avoid negative values in the total. The confidence index is the average of the sub-indexes, expressed it as a percent of the maximum possible average. $^{19}$

In the cases of Costa Rica and the Dominican Republic, their quarterly frequency indexes were interpolated into monthly ones (see Annex II: Frequency of the Model).

\footnotetext{
${ }^{19}$ Banguat has overhauled its monthly confidence index. It has implemented a new methodology to carry out its confidence survey as of 2019 , and as such, the new series is not comparable with the previous one.
} 


\section{ANNEX II. SOME METHODOLOGICAL NOTES}

This annex briefly discusses some methodological notes and test results pertaining to the estimation of the model. They involve:

\section{Frequency of the Model}

The VAR was initially run with quarterly data, but the degrees of freedom were low. Furthermore, by averaging the available monthly data to obtain quarterly indicators, some data richness information of the monthly data (particularly in terms of variability and bearing within the quarter) was lost with the transformation. ${ }^{20}$ For these reasons, we switched to monthly data.

\section{From Quarterly to Monthly Frequency}

A few simple interpolation methods were used. For example, in the case of private gross fixed investment (in real terms, seasonally adjusted), the quarterly observation in question was assumed to be the first monthly observation of the quarter; another assumption was that the average of the three monthly estimates be equal to the quarterly observation; the second and the third monthly observations were interpolated by using the geometric rate between the current (quarterly) observation and the next one. Two additional varieties of this method included: assuming that the quarterly observation be equal to the second or the third month of the quarter to be interpolated.

\section{The VAR and the Number of Lags}

When the VAR was estimated with 4 and 12 lags, the lag length tests (Schwarz Information Criterion, SC, Akaike, AIC, and Hannan-Quinn Information Criteria, HQ) suggested in the case of the former, that 2 lags would be appropriate, while in the case of the latter, the most reliable test of the three (HQ), still suggested 2 lags as appropriate.

\section{Non-Seasonally Adjusted Series (NSAS) versus Seasonally Adjusted Series (SAS)}

In an earlier draft of this paper, we run the model using both non-seasonally and seasonally adjusted data. To smooth the impact of seasonality in the NSAS, 12 lags were used. The test results for NSAS were in general weaker than those for SAS (e.g., in the correlogram, the NSAS had one third of their autocorrelations above 2 standard deviations, while for SAS it was only one sixth). More discouraging, when the VAR with NSAS was estimated using 12 lags (as suggested by the HQ test), it yielded three polynomial roots outside the unit circle, precluding convergence of the model towards equilibrium when NSAS are used. For these reasons, we omitted the NSAS in this version of the paper.

\section{Estimating the Impact of Changes in the Exogenous Variables in a VAR}

The exogenous block $X_{t}$ cannot be combined with the endogenous variables $Y_{t}$ to estimate their overall impact on a VAR system since, by definition, the (domestic) endogenous

\footnotetext{
${ }^{20}$ By the same token, when quarterly data was transformed into monthly frequency, it was impossible to add the richness in terms of variability and bearing to the transformed monthly data.
} 
variables cannot affect the (global) exogenous variables. Rather impulse responses were used to calculate the impact of changes arising from the exogenous block. A change in an exogenous variable in time $t$ is transmitted to $t+1, t+2 \ldots t+N-1$ ( $N$ is the size of the sample) and its impact is measured by the impulse responses in each period. The impact in the next period $t+1$, independent from the previous one in time $t$, is transmitted to $t+2, t+3 \ldots t+N-2$. The overall impact of changes for each of the exogenous variable will be the summation of $\mathrm{N}$ partial aggregations.

\section{Estimating the Contributions of Structural Shocks}

If the estimated shock in the period in question had the same sign as the residual of the factor being explained, the contribution of this shock was acknowledged, otherwise it was omitted with a zero value. This procedure yielded periods whose components for a specific period were all either positive (including zeros) or negative (including zeros) shocks. The absolute value was then applied and figures corresponding to the shocks of each factor were added over time (the absolute value was taken because the residual was either positive or negative and a simple aggregation would have largely cancelled itself out). Once these summations were calculated for each factor in each sub-period, the results were expressed as percent of the totals. This is just an approximation since the historical decomposition of the residual, in each period, does not necessarily yield shocks that are purely positive or negative. 


\section{ANNEX III. HistoRICAL DECOMPOSITION OF THE INVESTMENT RESIDUAL}

This annex shows the historical decomposition of the investment residual in a graphical representation for the countries in our sample.

\section{Costa Rica}

Figure AllI.1: Historical Decomposition of the Investment Residual - CRI (Log of Investment)

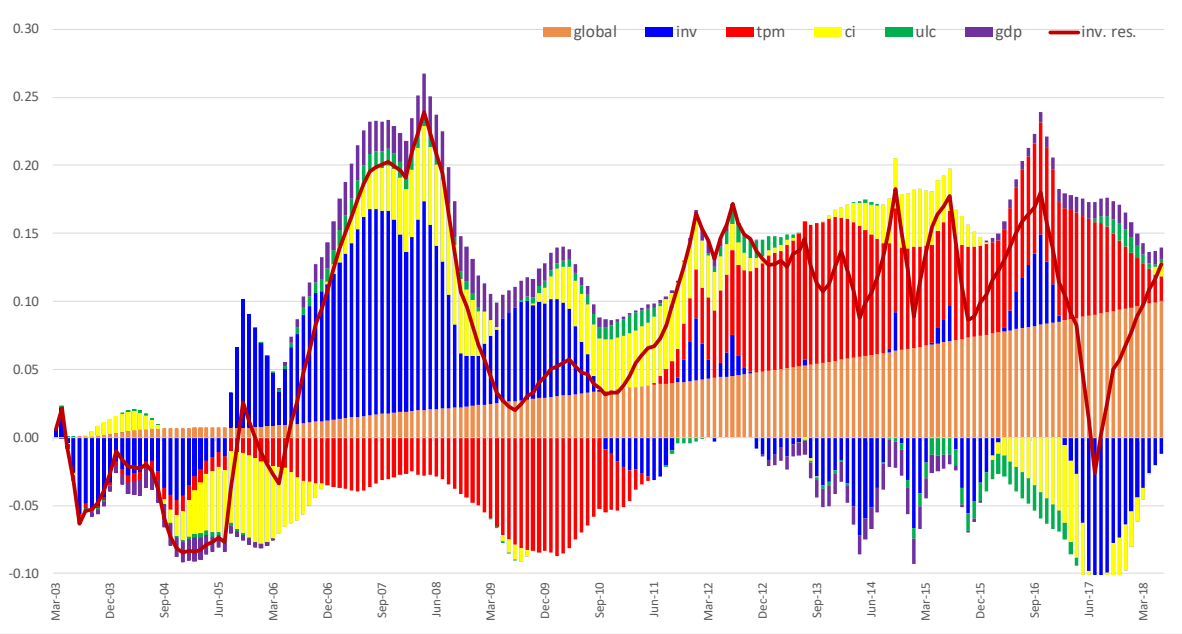

Source: IMF staff estimates.

\section{The Dominican Republic}

Figure Alll.2: Historical Decomposition of the Investment Residual - DOM (Log of Investment)

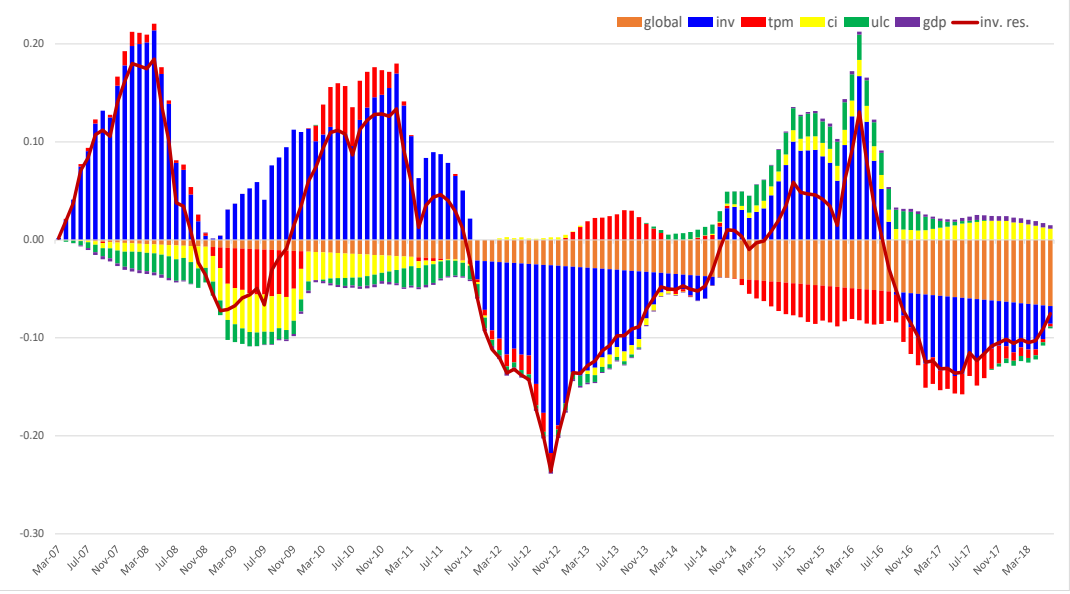

Source: IMF staff estimates. 


\section{El Salvador}

Figure Alll.3. Historical Decomposition of the Investment Residual - SLV (Log of Investment)

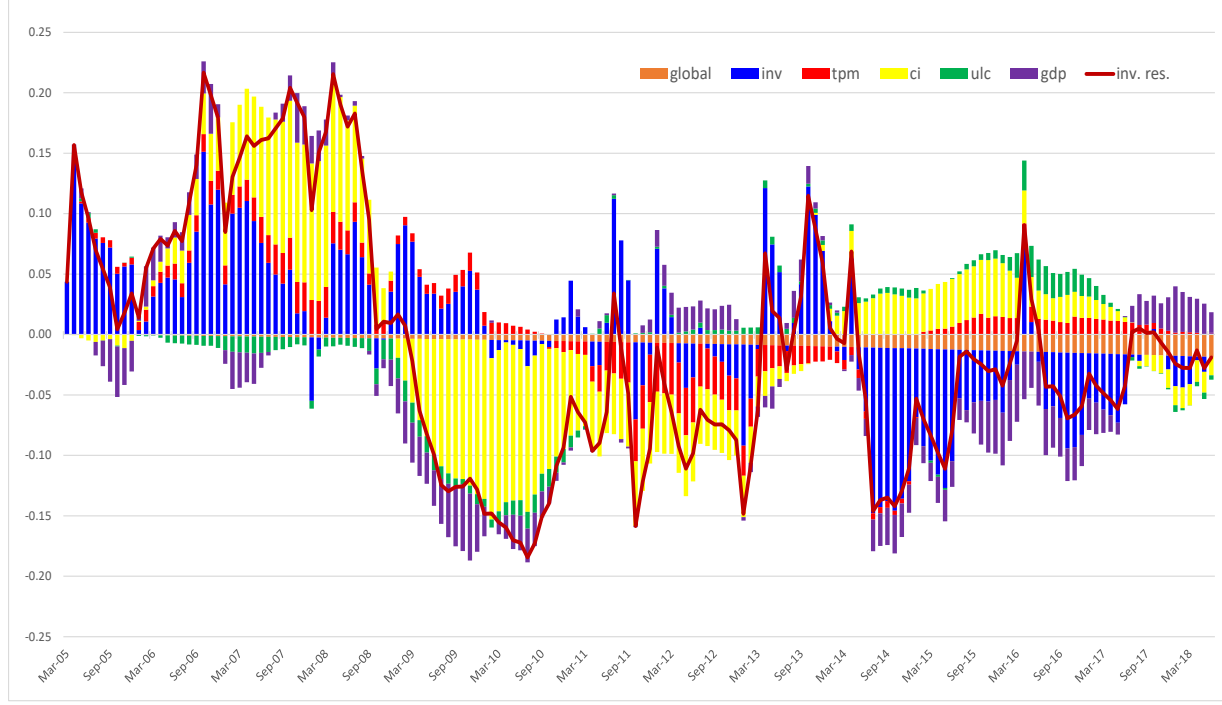

\section{Guatemala}

Figure Alll.4. Historical Decomposition of the Investment Residual - GTM (Log of Investment)

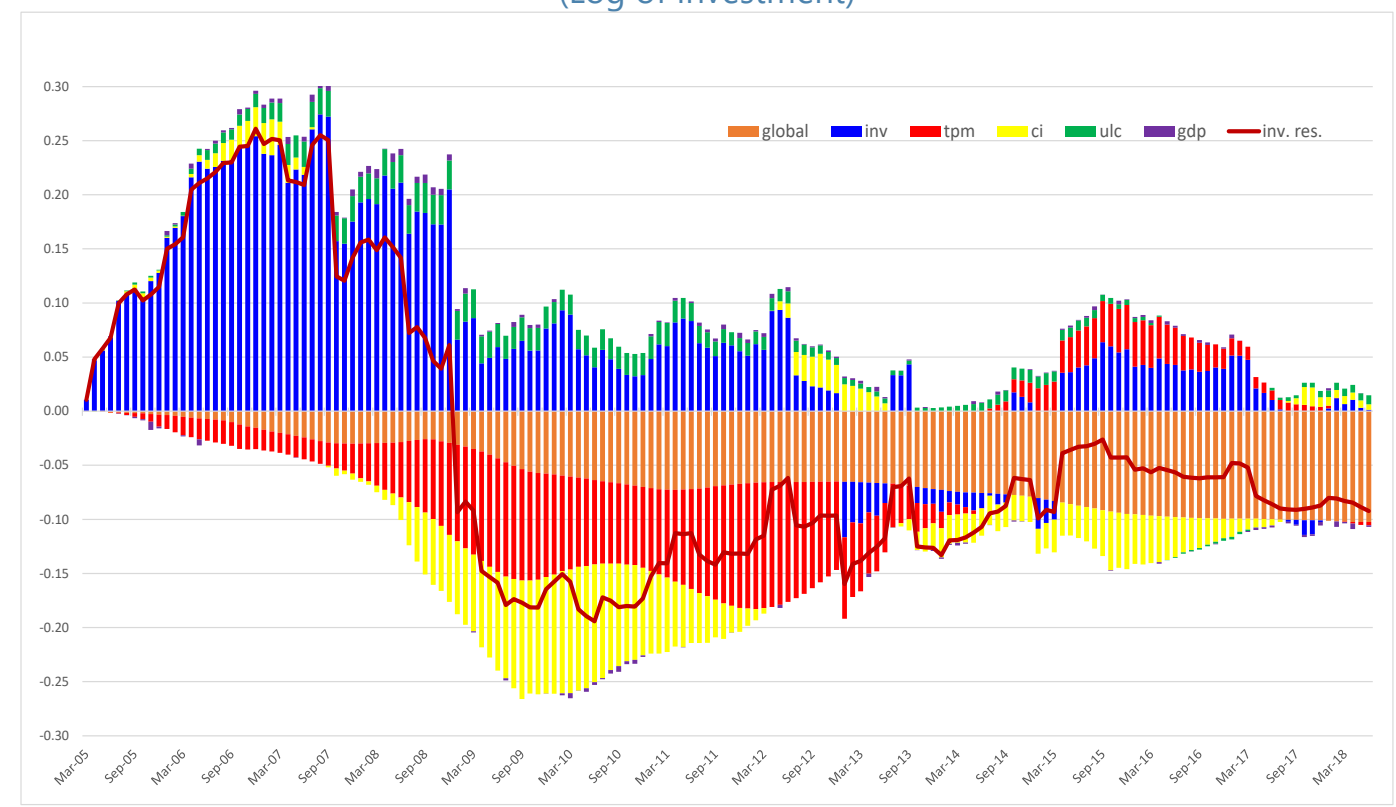

Source: IMF staff estimates. 


\section{REFERENCES}

Albagli E. and E. Luttini, 2015, "Expectativas, Incertidumbre, e Inversión en Chile: Evidencia Macro y Micro de la Encuesta IMCE," Mimeo, Central Bank of Chile.

Bachmann, R., S. Elstner and E. Sims, 2013, "Uncertainty and Economic Activity: Evidence from Business Survey Data," American Economic Journal: Macroeconomics, Vol. 5, No 2, pages $217-49$.

Beaudry, P., and F. Portier, 2006, "Stock Prices, News, and Economic Fluctuations," American Economic Review, 96 (4), pages 1293-307.

Bloom, N., 2009, “The Impact of Uncertainty Shocks,” Econometrica, Vol. 77 No 3, pages $623-85$.

Bloom, N., S. Bond, and J. Van Reenen, 2006, "Uncertainty and Investment Dynamics", National Bureau of Economic Research, Working Paper 12383.

Bonilla, M. I., 2014, "Propuesta para Establecer Una Política Industrial Basada en la Competitividad y la Innovación para Guatemala 2014-44”, Mimeo.

Burbidge, J., and A. Harrison, 1985, "A Historical Decomposition of the Great Depression to Determine the Role of Money," Journal of Monetary Economics, Vol. 16, pages 45-54.

Carriere-Swallow, Y., and L. F. Céspedes, 2011, "The Impact of Uncertainty Shocks in Emerging Economies," Central Bank of Chile, Working Papers No 646.

Canova, F., 2007, “Methods for Applied Macroeconomic Research” Princeton University Press.

Cuthberson, K., 2002, "Quantitative Financial Economics: Stocks, Bonds and Foreign Exchange" John Wiley and Sons, New York.

Figliuoli, L. and R. García-Saltos (editors), 2019, "Paving the way to growth and prosperity in Central America, Panama and Dominican Republic" IMF, Forthcoming.

International Monetary Fund, Western Hemisphere Regional Economic Outlook, April 2017, "Drivers of Capital Flows and the Role of the Investor Base in Latin America".

Kilian, L., 2011, “Structural Vector Autoregressions” University of Michigan.

Mayorga-Balladares, F. J. and A. I. Flores Sarria, 2010, "Banco Central, Inflación y Crecimiento Económico: El Caso de Guatemala,” Central Bank of Guatemala, Working Papers No 116. 
Sánchez-Fung, J., 2009, "Modelación de la Inversión en Centroamérica y la República Dominicana", Cuadernos de Economía, 28(51), 245-64.

World Bank Group and PwC, 2017, "Paying Taxes 2017: The Global Picture”. 